\title{
The Impact of Corporate Cultural Behaviour on Common Stock Return: Some Implications for Corporate Governance
}

\begin{abstract}
This paper examines the relationship between common stock return and corporate cultural behaviour of twenty listed firms from Shanghai Stock Exchange. The particular research questions of this study include: whether corporate cultural behaviour impacts common stock returns and under what conditions it impacts shareholder expectations and corporate governance.

Keywords: corporate cultural behaviour, mood state, stock return, shareholder wealth, weather.

Straipsnyje nagrinejjama bendrosios akcijų grąžos ir ịmonių kultūrinio elgesio sąsaja, pasireiškianti dvidešimtyje Šanchajaus akcijų biržos įmonių. Tyrime analizuojami klausimai: ar ịmonių kultūrinis elgesys daro ịtaką bendrajai akcijų grąžai ir kokiomis sąlygomis daroma ịtaka akcininkų lūkesčiams ir įmonių valdymui.

Raktiniai žodžiai: įmonių kultūrinis elgesys, nuotaikos būklè, akcijų grąža, akcininkų turtas, klimatas.
\end{abstract}

\section{Introduction}

The principle financial objective of a firm is to maximize the wealth of its common stockholders. In this exercise, allocation of organizational resources among business functions (e.g., marketing, operations) is a critical decision as it affects the business strategy of the firm. In order to maximize the wealth of common stockholders, managers must ensure that the organizational resources are allocated efficiently and effectively among business functions as overall rate of return to ordinary shareholders is determined by the aggregate sum of earnings generated by the business. Each function of an or- ganization is governed by a set of values of the organization. A quantitative assessment and consideration of business values (business cultural values) on financial objectives is extremely important. On the other hand, the value system of a business has an impact on the business strategy and ultimately the performance of the organization.

D. Ravasi and M. Schultz (2006) identify organizational culture as a set of shared mental assumptions that guide interpretation and action in organizations by defining appropriate behaviour for various situations. It is a unique behaviour of members accepted within the organization in achieving the corporate 
strategy. It is therefore apparent from contemporary thoughts that the corporate culture is about how the members of the organization influence the business strategy and the value system governing the conduct of business towards achieving the business (corporate) strategy. The behaviour of members within the organization is therefore a deterministic element of the value (or strategic corporate worth) of business. The literature recognizes the behaviour of organizational members as a salient feature of the corporate culture (see e.g., Kotter 1992; Kotter and James, 1992; Shrafritz and Ott, 1992; Deal and Kennedy, 2000; Charles and Gareth, 2001; Schrodt, 2002; Sørensen, 2002; Nelson and Quick, 2011; Schein, 2011; Kotter, 2012; Lunenburg, 2012) whereas Charles and Gareth (2001) define organizational culture as the specific collection of values and norms that are shared by people and groups in an organization and that control the way they interact with each other and with stakeholders outside the organization'.

Corporate culture plays an important role in financial management. Abdul Rashid et al. (2003) examine the influence of corporate culture and organizational commitment on financial performance in Malaysian firms and find that the corporate culture is significantly related to the organizational commitment and corporate performance. They also find that the organizational commitment has an influence on the financial performance. K. Kant (2017) carries out a survey on the relationship between corporate strategy and profitability of 96 firms from various sectors with different sizes. The respondents of the firms in the sample consist of top management executives such as chief executive officers, managing directors, directors. The study finds that the firms whose culture aligned with business (corporate strategy) strategy tend to report higher profitability than that of firms whose culture is not aligned with corporate strategy which report lower profitability. He also emphasizes that 'The organizational culture affects the way employees interact with each other, with customers and other stakeholders, besides their perception of the organization. This, in turn, impacts other stakeholders' perception about the company, adds Bhinge.

National culture differs from organizational culture (Denison, 1990) although 'people' factor is involved in bother cultures and the culture can be viewed as a behaviour of 'people' involved in an organization. M. O. Agwu (2014) finds a significant relationship between organizational culture, and increased employee commitment and productivity in National Agency for Food and Drugs Administration and Control in Nigeria. The following chart (Figure 1) illustrates

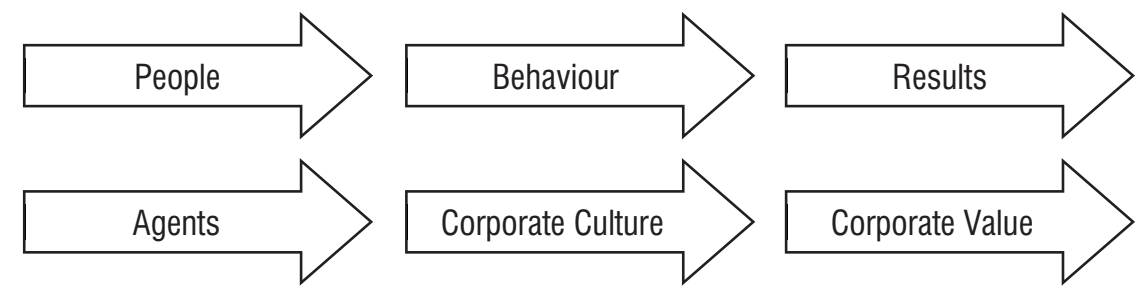

Fig. 1. Corporate culture and corporate value 
the linkage between 'people' and corporate value in brief.

As figured above, the values of individual agents drive the behaviour and these values are assumed to be homogeneous and aligned with the corporate strategy. It is however assumed that these values are not aligned with agents' own objectives and there is no agency problem (i.e. conflict of interest between agents and the equity holders) in the firms under consideration. Behaviour of agents collectively determines the results of the organization. The line two views the process from financial management perspective whereas line one views such from general management perspective.

The profitability determines the ultimate value of the firm as retained earnings are carried forward in reserves for equity holders. Eventually, the profitability determines the ultimate value of the stake of common stocks and the profitability is achieved through the direct actions of members of the organization which reflect the perceived behaviour. On the other hand, the theories of market efficiency suggest that the human behaviour is not a deterministic function of shareholder wealth (See e.g., Fama, 1965). E. de Jong and R. Semenov (2002) demonstrate that cultural elements such as uncertainty avoidance and higher levels of masculinity have an impact on equity market development whereas C. W. Senarathne et al. (2017) examine the relationship between national cultural dimension, collectivism-individualism and the stock market return of ten well established stock exchanges of the world and find no sufficient evidence to generalize the existence of such relationship in the stock markets. The linkage between stock return and cor- porate culture when human behaviour is governed by a firm-specific value system is not broadly documented in the literature. However, a number of scholars such as R. Comment and G. W. Schwert (1995), D. Yermack (2006), D. Kadyrzhanova and M. Rhodes-Kropf (2011), V. Cunat et al. (2012) and J. Asker et al. (2014) discuss about the effect of shareholder governance on firm value. A recent work of Popadak (2015) finds that the corporate culture is an important element through which the shareholder governance affects the firm value because shareholder governance is associated corporate culture. It is therefore plausible to surmise that corporate cultural behaviour may influence the shareholder return when firms do not align their culture with corporate financial objectives. Note that the priority is given to strategies that are directly related to shareholder wealth maximization principle.

The objective of this paper is to examine the relationship between common stock return and corporate cultural behaviour of randomly selected twenty listed firms from the Shanghai Stock Exchange. The particular research questions of this study include; whether the corporate cultural behaviour impacts common stock returns and under what conditions it impacts shareholder expectations and corporate governance. The tasks and research methods include computing the value of variable, which reflects the corporate cultural behaviour, according to the conceptual framework and applying Ordinary Least Square (OLS) regression technique to determine the impact of corporate cultural behaviour on common stock return. Further, Binary Logistic Regression technique is used to understand 
the reasonableness of the role of temperature in the computations and final regressions. The results show that the corporate actions derived from corporate cultural behaviour do not impact stock return when firms do not align their operations with direct interest of shareholders and common stockholders tend to claim a premium when their expectations are not met by the firms in the course of business operation.

Section two provides the methodological framework for the study and section three discusses the findings, along with sample selection and descriptions of data. Section four provides concluding remarks.

\section{Methodological framework}

In order to identify the relationship between return of equity holders and corporate culture, one must assign a numerical measure for corporate cultural behaviour. A number of scholars in the finance literature consider weather variables such as temperature, rain, sunshine as quantitative measures of mood (see e.g., Saunders 1993; Hirshleifer and Shumway 2003; Keef and Roush, 2007) and the relationship between weather and human behaviour as mediated by human mood is well established in social psychology (see e.g., Bell and Baron, 1976; Cunningham, 1979; Howarth and Hoffman, 1984). Saunders (1993). The relationship between weather and human behaviour is clearly negative because the influence of bad weather (e.g. high temperature) results in poor mood state that leads to deviation in the normal behaviour of human, for example, aggression, anger. Trading (trading decisions) under the condition of affected behaviour is therefore not optimal. Hence, it im- pacts the price change process negatively. D. Hirshleifer and T. Shumway (2003) and many others demonstrate that the human behaviour influences stock price changes.

Each operational event of a firm results in change in wealth of equity holders which will theoretically be the change in the market price (cum dividend) of the firm. Assume that the book value per share of firm $i$ at time $t\left(V_{i t}\right)$ is equal to the market value (price) $P_{i t}$ of firm $i$ at time $t$ because the firm's stock is trading in a market which largely converges to a Tobin's (1984) or Roll's (1988) version of efficiency. Each operational event is associated with human behaviour of 'people' within the firm which is observed by the operational time of the market (i.e. the trading event) such that a new equilibrium market price is determined. The return $r_{i t}$ attributable to equity of firm $i$ at time $t$ becomes $r_{i t}=\left(P_{i t}-P_{i t-1}\right) / P_{i t-1}$. In the sense of Black (1972), return of common stock holders can be forecasted in an efficient equity market in such way that;

$$
r_{i t}=\beta_{0}+\beta_{m} r_{m t}+\varepsilon_{t},
$$

where $r_{m}$ is the return on market portfolio at time $t$ and $\varepsilon_{t}$ is payoffs attributable (stochastic noise) to equity holders on firm-specific information events (i.e. human operation) observed at each operational time $t$ in the market and $\beta_{0}+\beta_{m} r_{m t}$ is the mean (let it also be denoted as $\mu$ ) of return conditional on information set $I$ available to investors at time $t$ (note that payoffs $\varepsilon_{t}$ is under direct control of the individual firms). On the assumption of classical Ordinary Least Square (OLS) regression for homoscedasticity of residuals, $E\left(\varepsilon_{t} \mid r_{m t}\right)=0$. Since the market is assumed to be 
efficient, $E\left(\varepsilon_{t} \mid n_{t}\right) \geq 0$ where $n_{t}$ is the operation $n$ at time $t$. Also, at each operation directed by observation $n$ at time $t$, $\varepsilon_{t} \mid n_{t} \sim N\left(0, \sigma^{2} n_{t}\right) \quad$ (see Clark, 1973; Lamoureux and Lastrapes, 1990; Senarathne and Jianguo, 2017; Senarathne and Jayasinghe, 2017; Senarathne and Long, 2018 for a complete exposition). The market is assumed to be efficient so that the expectation of price changes conditional on firm-specific information events or corporate actions $n$ observed at each operational time, $E\left(r_{i} \mid n_{t}\right) \geq 0 . E\left(\mu \mid n_{t}\right)=0$ because the equity holders receive nothing from the market expectation (stock price changes are assumed to be completely random and determined only by the number of firm-specific new information arrival at the market on every corporate action) as price increments $P_{i t}-P_{i t-1}$ are subordinated to $\varepsilon_{t}$ and an increasing function of $t$ (see Clark, 1973, p. 139).

Temperature is used as the numerical proxy for mood state that acts as a mediator between human behaviour and weather on the assumption that the organizational culture is influenced by the mood state of human resources or 'people' of the organization. On the other hand, scholars demonstrate that the national culture influences employee behaviour in a work setting (see Schneider, 1988; Smith et al., 1996; Lok and Crawford, 2004) and their individual behaviour in general (see especially Schuler and Rogovsky, 1998). It is however assumed that individual differences of 'people' within the organization do not affect the corporate culture. The general behaviour of 'people' induced by mood states becomes a corporate cultural behaviour when 'people', as human resource, are attached to a particular organizational setting surrounded by a value system unique to the particular organization. When 'people' become human resource of an organization, a unique behaviour is formed within the organization that distinguishes from the general behaviour of 'people' (when they are outside the organization). A good example to explain behavioural change with respect to this phenomenon is that, consider an unconstrained and constrained mind when a person before and after seeing the notice of 'CCTV camera in operation' in the circumstances. Organizations develop their own values and culture within the particular work setting (see Hofstede, 1985; 1994; 2001). In some sense, 'people' suppress their real behaviour when they are attached to a particular work setting, governed by a unique value system. J. M. George and G. R. Jones (1996) specifically argue that the mood of employee is a critical determinant of behaviour. Mood fluctuates over time and the changes in mood state determine the particular culture at work. This is further testified by the work of Rest (1986) who suggests that mood may cause organization-wide consequences at the individuals' anticipation and business decision making process.

Human behaviour is part and parcel of the business operation, leading to achieving the ultimate objective of maximizing the value of business. Therefore, the employee behaviour is a determinant of the ultimate outcome of business process (i.e., value of firm). Corporate culture could ultimately be formed by the value attributable to corporate behaviour as a whole. Each operational event of an organization is driven by a particular behaviour of its 'people' which is observed by each trade of the firm's equity at the market and each trade results in a new equilibrium price 
determined in the market. Let $C_{i}$ be the corporate cultural behavior of firm $i$ and $b$ denotes the general behavior (when 'people' are not constrained by an organizational specific value system) mediated by mood state. At each operational event of the firm associated with corporate cultural behaviour (firm-specific) is observed by $n$ number of observations (note that the firm-specific information is available to equity holders at each observation of corporate cultural behaviour) at operational time $t$ which results in $\varepsilon_{t}$ amount of payoffs attributable to equity holders.

$$
C_{t}=\sum_{j=1}^{n_{t}} b_{t}\left|\varepsilon_{t}\right|
$$

Such that $\varepsilon_{t}=\sum_{j=1}^{n_{t}} \delta_{j t}$ where $\delta_{j}$ is the $j$ th intraday price increment at time $t$ which is summed up over a monthly data horizon (see Lamoureux and Lastrapes (1990) p. 222 for a similar preposition). With time subscript (operational time), equation 2 can be written as $C_{i t}=\sum_{j=1}^{n_{t}} b_{t}\left|\varepsilon_{t}\right|$ (a similar preposition is adopted in Ajzen, 1991). The logic of obtaining fitted residuals from the equation regressing return on market return rather than regressing market price on index value is that the price change, for example, from $P_{i t-1}$ to $P_{i t}$ is associated with or due to corporate actions. Temperature is taken as a proxy for $b$ in line with the existing literature (see especially Cao and Wei, 2005). Then, the relationship between corporate cultural behaviour and the common stock return could be examined by the following equation in the sense of D. Hirshleifer and T. Shumway (2003).

$$
r_{i t}=\theta_{0}+\beta_{1} C_{t}+\beta_{2} \text { TEMP }_{t}+\beta_{3} R_{A I N_{t}}+v_{t},
$$

where $v_{t}$ is assumed to be well behaved. Under null hypothesis of corporate cultural behaviour influences stockholder return $\beta_{1}$ should be statistically significant and negative. Specifically, poor mood state affected by bad weather should result in lower return and, vice versa. TEMP and $R A I N$ are the control variables namely the temperature and rain at respective operational time. When this behaviour is standardized with respect to $n_{t}$ amount of firm-specific or corporate specific operational events or behavioural actions accruing $\varepsilon_{t}$ amount of payoffs (firm-specific payoffs) to their equity holders, poor corporate (cultural) behaviour (corporate cultural behaviour will be poor when $C_{t}$ is high) should result in lower return and, vice versa. The corporate actions are induced by a particular behaviour within the corporation. Note that, not only investors who trade in stocks but also the mood of 'people' within the firms are affected by bad weather. Sign of the coefficient is more important in order to establish the expected relationship and the significance is dependent upon, to what extent the corporate culture is aligned with shareholder value maximizing principle (i.e., meeting the expectations of shareholders).

The coefficient estimates may however be subject to significant variation in metrological phenomenon of cities. Although the temperature is a medically testified proxy variable for mood state (see especially Keller et al., 2005), one must establish the fact that the sign of the coefficients truly represents the relationship between human behaviour and stock return. Consider the following specification,

$$
P\left(r_{i t}>0\right)=\alpha_{1}+\beta_{4} T E M P+v_{t}
$$


where $\beta_{4}$ is the estimate from the logit regression and $v_{t}$ is the error term which is assumed to be well behaved. The corresponding probability $(p)$ of the estimate at unity (a variable) is given by,

$$
P\left(r_{i t}>0\right)=\frac{e^{\left(\alpha_{1}+\beta_{5} \text { TEMP }\right)}}{e^{\left(\alpha_{1}+\beta_{5} T E M P\right)}+1}
$$

In order to ensure that the equation (3) is specified in this respect, the following logit regression model is employed where the parameters are estimated by Maximum Likelihood (ML) method.

$$
\ln \left(\frac{p}{1-p}\right)=\alpha_{1}+\beta_{6} T E M P+v_{t}
$$

For logit regression, $Y=\alpha_{1}+\beta_{6} T E M P+v_{t}$ where Dummy variable $Y$ takes the value 1 for all positive return observations and the coefficient $\beta_{6}$ should be negative and statistically significant if equation (3) is specified as per the conceptual model (see Table 2 for estimated probabilities).

\section{Data and findings}

\section{Data}

Twenty listed firms are selected from the firms listed in the Shanghai Stock Exchange on a random sampling basis. Type A shares (where only local counterparts are allowed to trade) are given high priority in the sample selection (the sample includes type A-shares) in order to ensure the reflection of country specific human behavioural factors in line with the conceptual framework. Returns are generated for a sampling period of 19 years from $31^{\text {st }}$ January 1997 (including January 1997) to $31^{\text {st }}$ December 2015. Data are available on webpage of the Shanghai Stock Exchange and Yahoo Finance webpage https:// finance.yahoo.com/. Month end closing prices are adjusted for dividend and stock splits. Dividend data for each firm are available at Yahoo Finance webpage. Monthly temperature data are obtained from Climate Change Knowledge Portal (CCKP) webpage of World Bank Group. Some descriptive statistics of the sample data are given in Table 1.

\section{Empirical findings}

Except for firm 9, 17 and 20 whose unconditional returns are normally distributed, unconditional distributions of return and the variable computed for corporate cultural behavior $(C)$ are clearly nonnormal as JB test statistic exceeds its critical value of 5.99 at $5 \%$ statistical significance level. Statistical properties such as skewness and kurtosis of return and $C$ exist for firms violating normality assumption. The minimum value of $C$ is less than zero and maximum value is positive for all firms, justifying sufficient variations in weather conditions under four seasons namely summer, winter, spring and autumn. China provides a good support for the conceptual framework given the significant variation in the weather (i.e., temperature) over the four seasons (see Zhang et al., 2017). Except for firm 8, the null hypothesis for return and $C$ having unit root under $\mathrm{ADF}$ test is rejected for all firms as the test statistic falls below the critical value of -2.87 at $5 \%$ significance level. However, variable $C$ of firm 8 is subject to a unit root as the test statistic remains at -1.919 . Regression for each firm covers a good number of observations to invoke the law of large 
Table 1. Descriptive statistics of sample

\begin{tabular}{|c|c|c|c|c|c|c|c|c|c|c|c|c|}
\hline No & Firm & V.ble & Obs & JB & $\mathrm{ADF}$ & Mean & Median & $\operatorname{Max}$ & Min & $\begin{array}{l}\text { Std. } \\
\text { Dev. }\end{array}$ & Skew & Kurt \\
\hline \multirow{2}{*}{1} & \multirow{2}{*}{$\begin{array}{l}\text { Kunwu Jiuding In- } \\
\text { vestment Holdings }\end{array}$} & $r$ & 224 & 1743 & -12.62 & 0.007 & 0.000 & & -0.419 & 0.164 & 1.780 & 1610 \\
\hline & & $c$ & 224 & 184 & -8.842 & 0.766 & 0.269 & 7.674 & -2.430 & 1.593 & 1.614 & 6.061 \\
\hline \multirow{2}{*}{2} & \multirow{2}{*}{ Citic Guoan Wine } & $r$ & 222 & 152 & -12.66 & 0.003 & -0.002 & 0.680 & -0.541 & 0.133 & 0.077 & 7.063 \\
\hline & & $c$ & 222 & 232 & -9.535 & 0.495 & 0.250 & 4.596 & -1.734 & 1.016 & 1.570 & 6.914 \\
\hline \multirow{2}{*}{3} & \multirow{2}{*}{ China Meheco } & & 224 & 7.0 & -14.72 & & & & & 0.124 & -0.021 & 3.863 \\
\hline & & $r$ & 224 & 169 & -2.958 & 0.558 & 0.238 & 4.668 & -0.968 & 0.941 & 1.603 & 5.797 \\
\hline \multirow{2}{*}{4} & \multirow{2}{*}{$\begin{array}{l}\text { China Resources } \\
\text { Double-Crane }\end{array}$} & $c$ & 224 & 313 & -5.258 & 0.006 & 0.013 & 0.342 & -0.697 & 0.122 & -1.224 & 8.251 \\
\hline & & $r$ & 224 & 1414 & -8.665 & 0.663 & 0.281 & 8.544 & & 1.323 & 2.717 & 14.04 \\
\hline \multirow{2}{*}{5} & \multirow{2}{*}{$\begin{array}{c}\text { Shanghai Maling } \\
\text { Aquarius }\end{array}$} & $c$ & 222 & & & & & & & 0.152 & & \\
\hline & & $r$ & 222 & 656 & & & & & & & 1.960 & 10.45 \\
\hline \multirow{2}{*}{6} & \multirow{2}{*}{ Xinjiang Tianye Co. } & $c$ & 223 & 150 & -15.29 & 0.004 & 0.004 & 0.579 & -0.709 & 0.146 & -0.511 & 6.892 \\
\hline & & $r$ & 223 & 9643 & -8.322 & 0.677 & 0.288 & 14.03 & -1.819 & 1.481 & 4.292 & 34.05 \\
\hline \multirow{2}{*}{7} & \multirow{2}{*}{$\begin{array}{c}\text { China Cyts Tours } \\
\text { Holding }\end{array}$} & $c$ & 217 & 83.5 & -13.21 & 0.010 & 0.006 & 0.499 & & 0.125 & -0.086 & 6.034 \\
\hline & & $r$ & 217 & 787 & -9.068 & & & & & 1.133 & & 11.48 \\
\hline \multirow{2}{*}{8} & \multirow{2}{*}{$\begin{array}{l}\text { Hubei Xingfa } \\
\text { Chemicals }\end{array}$} & $c$ & 199 & & & & & & & & & \\
\hline & & $r$ & 199 & 1435 & -1.919 & 0.599 & & 8.677 & & 1.220 & 2.719 & 14.97 \\
\hline \multirow{2}{*}{9} & \multirow{2}{*}{$\begin{array}{l}\text { Sundy Land } \\
\text { Investment }\end{array}$} & $c$ & 224 & & -14.09 & 0.003 & -0.002 & 0.366 & & 0.146 & -0.168 & 3.267 \\
\hline & & $r$ & 224 & 86.3 & -10.24 & 0.680 & 0.341 & 5.436 & -2.260 & 1.201 & 1.183 & 4.909 \\
\hline \multirow{2}{*}{10} & \multirow{2}{*}{$\begin{array}{c}\text { Eastern Gold Jade } \\
\text { Company }\end{array}$} & $c$ & 223 & & & & & & & & & \\
\hline & & $r$ & 223 & 7580 & & & & & & 2.140 & & 0.21 \\
\hline \multirow{2}{*}{11} & & $c$ & 223 & & & & & & & & & 4.037 \\
\hline & & $r$ & 223 & & & & & & & .169 & 1.775 & 9.465 \\
\hline & & $c$ & 222 & 60.9 & -15.17 & 0.005 & 0.001 & 0.483 & -0.425 & .118 & 353 & 5.467 \\
\hline & & $r$ & 222 & 69.7 & -8.877 & 0.387 & 0.216 & 3.333 & & 0.788 & 0.787 & 5.249 \\
\hline & & $c$ & 223 & & & & & & & 115 & & 258 \\
\hline 13 & & $r$ & 223 & & & & & & & 366 & 511 & 109 \\
\hline & & $c$ & 220 & 39.0 & & & & & & 0.139 & -0.060 & 5.059 \\
\hline 14 & & $r$ & 220 & & & 0.548 & 0.229 & 7.106 & -1.634 & 1.133 & 2.162 & 10.39 \\
\hline 15 & & $c$ & & 1232 & & & & & & & 1.404 & 14.28 \\
\hline 15 & & $r$ & 219 & & & & & 5.894 & & 1.052 & .026 & 9.056 \\
\hline & & $c$ & 204 & 3033 & & & & & 944 & .172 & .121 & 21.75 \\
\hline 16 & & $r$ & 204 & 2308 & & & & & & 1.280 & -1.664 & 19.14 \\
\hline & & $c$ & 221 & & & & & & & & & 3.026 \\
\hline & & $r$ & 221 & 58.1 & -10.31 & 0.511 & 0.312 & 4.094 & -2.344 & 0.942 & 0.895 & 4.763 \\
\hline 18 & & $c$ & 213 & 41.6 & -12.57 & 0.005 & 0.003 & 0.476 & -0.520 & 0.134 & 0.148 & 5.144 \\
\hline 18 & & $r$ & 213 & 1181 & -8.543 & 0.588 & 0.278 & 7.843 & -1.686 & 1.234 & 2.666 & 13.22 \\
\hline 1 & & $c$ & 205 & & & & & & & 0.138 & 0.536 & 6.293 \\
\hline 19 & & $r$ & 205 & 317 & -8.557 & 0.495 & & 5.375 & & 1.020 & 1.653 & 8.124 \\
\hline & & $c$ & 212 & 4.9 & -13.69 & 0.007 & 0.001 & 0.374 & -0.367 & 0.118 & -0.011 & 3.743 \\
\hline & & $r$ & 212 & 44 & -9.878 & 0.529 & 0.256 & 3.405 & -1.418 & 0.941 & 1.042 & 3.835 \\
\hline & & $T$ & 221 & 19.9 & -3.14 & 7.144 & 8.356 & 20.60 & -10.82 & 9.747 & -0.186 & 1.598 \\
\hline & 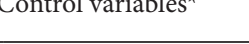 & $R$ & 221 & 23.1 & -3.167 & 47.45 & 36.96 & 128.9 & 4.073 & 34.85 & 0.627 & 2.030 \\
\hline
\end{tabular}

Notes:

1. JB - Jarque-Bera test statistic for normality. Under null hypothesis for normality, critical value of $\chi 2$ (2) distribution at $5 \%$ significance level is 5.99

2. ADF- Augmented Dickey-Fuller test statistic for stationarity of returns for maximum 15 lags. Under null hypothesis for residuals having unit root, the critical value at $5 \%$ significance level is -2.87 .

3. $T$ stands for TEMP and $R$ stands for RAIN. 
Table 2. Empirical test results

\begin{tabular}{|c|c|c|c|c|c|c|c|}
\hline No & Firm & $\beta_{m}$ & $\beta_{1}$ & $\beta_{2}$ & $\beta_{3}$ & $\beta_{6}$ & $\hat{p}$ \\
\hline 1 & Kunwu Jiuding Investment Holdings & $\begin{array}{c}0.125 \\
(1.376)\end{array}$ & $\begin{array}{l}-0.022^{\star *} \\
(-1.702)\end{array}$ & $\begin{array}{l}7.3 \mathrm{E}-05 \\
(0.061)\end{array}$ & $\begin{array}{l}-1.9 \mathrm{E}-04 \\
(-0.502)\end{array}$ & $\begin{array}{c}-0.027^{* *} \\
(1.895)\end{array}$ & $49 \%$ \\
\hline 2 & Citic Guoan Wine & $\begin{array}{l}0.948^{*} \\
(7.224) \\
\end{array}$ & $\begin{array}{c}-0.020 \\
(-0.601) \\
\end{array}$ & $\begin{array}{c}-0.001 \\
(-0.309) \\
\end{array}$ & $\begin{array}{r}-5.0 \mathrm{E}-07 \\
(-0.001) \\
\end{array}$ & $\begin{array}{l}-0.038^{*} \\
(-2.672) \\
\end{array}$ & $54 \%$ \\
\hline 3 & China Meheco & $\begin{array}{c}1.086^{\star} \\
(13.493)\end{array}$ & $\begin{array}{l}0.022^{* *} \\
(1.771)\end{array}$ & $\begin{array}{l}-0.003^{*} \\
(-2.672)\end{array}$ & $\begin{array}{l}1.3 \mathrm{E}-04 \\
(0.624)\end{array}$ & $\begin{array}{c}-0.020^{* * *} \\
(-1.457)\end{array}$ & $55 \%$ \\
\hline 4 & China Resources Double-Crane & $\begin{array}{l}0.659^{\star} \\
(6.394) \\
\end{array}$ & $\begin{array}{l}-0.042^{*} \\
(-2.928) \\
\end{array}$ & $\begin{array}{l}0.002^{*} \\
(2.044) \\
\end{array}$ & $\begin{array}{l}-1.3 \mathrm{E}-04 \\
(-0.704) \\
\end{array}$ & $\begin{array}{l}-0.026^{\star *} \\
(-1.820) \\
\end{array}$ & $62 \%$ \\
\hline 5 & Shanghai Maling Aquarius & $\begin{array}{l}0.914^{*} \\
(5.939) \\
\end{array}$ & $\begin{array}{c}-0.001 \\
(-0.030) \\
\end{array}$ & $\begin{array}{l}-8.3 \mathrm{E}-04 \\
(-0.345) \\
\end{array}$ & $\begin{array}{l}3.6 \mathrm{E}-05 \\
(0.072) \\
\end{array}$ & $\begin{array}{c}-0.014 \\
(-0.991) \\
\end{array}$ & $55 \%$ \\
\hline 6 & Xinjiang Tianye Co. & $\begin{array}{l}0.972^{\star} \\
(7.768)\end{array}$ & $\begin{array}{c}-0.018 \\
(-1.242) \\
\end{array}$ & $\begin{array}{l}-8.1 \mathrm{E}-04 \\
(-0.619)\end{array}$ & $\begin{array}{l}3.1 \mathrm{E}-04 \\
(-1.161) \\
\end{array}$ & $\begin{array}{c}-0.013 \\
(-0.956)\end{array}$ & $55 \%$ \\
\hline 7 & China Cyts Tours Holding & $\begin{array}{l}0.921^{*} \\
(8.135)\end{array}$ & $\begin{array}{l}-0.034^{* *} \\
(-1.650)\end{array}$ & $\begin{array}{l}4.8 \mathrm{E}-04 \\
(0.342)\end{array}$ & $\begin{array}{c}2.8 \mathrm{E}-04 \\
(0.869)\end{array}$ & $\begin{array}{l}-0.024^{*} \\
(-1.694)\end{array}$ & $56 \%$ \\
\hline 8 & Hubei Xingfa Chemicals & $\begin{array}{l}0.994^{*} \\
(6.174) \\
\end{array}$ & $\begin{array}{l}-0.039^{\star} \\
(-1.998) \\
\end{array}$ & $\begin{array}{c}0.001 \\
(1.101) \\
\end{array}$ & $\begin{array}{l}5.2 \mathrm{E}-05 \\
(0.204) \\
\end{array}$ & $\begin{array}{c}-0.014 \\
(-0.929) \\
\end{array}$ & $54 \%$ \\
\hline 9 & Sundy Land Investment & $\begin{array}{l}1.102^{*} \\
(9.586) \\
\end{array}$ & $\begin{array}{c}-0.010 \\
(-0.532) \\
\end{array}$ & $\begin{array}{c}-0.002 \\
(-1.121) \\
\end{array}$ & $\begin{array}{l}-6.9 \mathrm{E}-05 \\
(-0.282) \\
\end{array}$ & $\begin{array}{l}-0.043^{\star} \\
(-3.032) \\
\end{array}$ & $55 \%$ \\
\hline 10 & Eastern Gold Jade Company & $\begin{array}{l}0.966^{*} \\
(6.121)\end{array}$ & $\begin{array}{c}0.013 \\
(0.888)\end{array}$ & $\begin{array}{c}-0.001 \\
(-0.679)\end{array}$ & $\begin{array}{l}1.8 \mathrm{E}-04 \\
(0.467)\end{array}$ & $\begin{array}{c}0.005 \\
(0.391)\end{array}$ & $52 \%$ \\
\hline 11 & Easysight Supply Chain Management & $\begin{array}{l}0.818^{*} \\
(5.848)\end{array}$ & $\begin{array}{c}0.002 \\
(0.085)\end{array}$ & $\begin{array}{l}-0.002^{* * *} \\
(-1.510)\end{array}$ & $\begin{array}{l}-3.3 \mathrm{E}-04 \\
(-1.195)\end{array}$ & $\begin{array}{l}-0.033^{*} \\
(-2.356)\end{array}$ & $53 \%$ \\
\hline 12 & Guangzhou Development Group & $\begin{array}{c}1.018^{*} \\
(12.103)\end{array}$ & $\begin{array}{c}-0.003 \\
(-0.132) \\
\end{array}$ & $\begin{array}{l}-9.6 \mathrm{E}-04 \\
(-0.545) \\
\end{array}$ & $\begin{array}{c}2.0 \mathrm{E}-04 \\
(0.518) \\
\end{array}$ & $\begin{array}{c}-0.014 \\
(-1.042) \\
\end{array}$ & $52 \%$ \\
\hline 13 & Sichuan Mingxing Electric Power Co & $\begin{array}{c}0.960^{*} \\
(11.296)\end{array}$ & $\begin{array}{c}-0.005 \\
(-0.215) \\
\end{array}$ & $\begin{array}{c}-9.3 \mathrm{E}-04 \\
(-0.666)\end{array}$ & $\begin{array}{l}1.1 \mathrm{E}-04 \\
(0.454)\end{array}$ & $\begin{array}{c}-0.023^{* * *} \\
(-1.614)\end{array}$ & $56 \%$ \\
\hline 14 & Jiangsu Etern Co., Ltd. & $\begin{array}{l}1.103^{*} \\
(8.119)\end{array}$ & $\begin{array}{c}0.010 \\
(0.485)\end{array}$ & $\begin{array}{c}-0.001 \\
(-0.543)\end{array}$ & $\begin{array}{c}2.3 \mathrm{E}-04 \\
(0.418)\end{array}$ & $\begin{array}{l}-0.023^{* *} \\
(-1.649)\end{array}$ & $52 \%$ \\
\hline 15 & Zhe Jiang Dong Ri Co., Ltd & $\begin{array}{l}0.955^{*} \\
(7.779) \\
\end{array}$ & $\begin{array}{c}-0.011 \\
(-0.565) \\
\end{array}$ & $\begin{array}{c}-0.001 \\
(-0.917) \\
\end{array}$ & $\begin{array}{l}3.0 \mathrm{E}-04 \\
(0.987) \\
\end{array}$ & $\begin{array}{l}-0.032^{*} \\
(-2.239) \\
\end{array}$ & $56 \%$ \\
\hline 16 & Jinyu Bio-Technology Co., Ltd & $\begin{array}{l}0.955^{\star} \\
(7.446)\end{array}$ & $\begin{array}{l}-0.026 \\
(-0.992) \\
\end{array}$ & $\begin{array}{c}0.000 \\
(0.158)\end{array}$ & $\begin{array}{l}1.0 \mathrm{E}-04 \\
(0.310)\end{array}$ & $\begin{array}{c}-0.015 \\
(-1.000)\end{array}$ & $62 \%$ \\
\hline 17 & Chongqing Three Gorges Water & $\begin{array}{c}0.893^{*} \\
(10.914)\end{array}$ & $\begin{array}{c}-0.007 \\
(-0.433)\end{array}$ & $\begin{array}{c}7.8 \mathrm{E}-04 \\
(0.299)\end{array}$ & $\begin{array}{c}5.0 \mathrm{E}-04 \\
(0.714)\end{array}$ & $\begin{array}{c}-0.005 \\
(-0.396)\end{array}$ & $54 \%$ \\
\hline 18 & Jiangsu Hongtu High Technology & $\begin{array}{l}0.947^{*} \\
(7.863)\end{array}$ & $\begin{array}{c}-0.018 \\
(-1.067) \\
\end{array}$ & $\begin{array}{l}-7.4 \mathrm{E}-04 \\
(-0.653) \\
\end{array}$ & $\begin{array}{l}1.4 \mathrm{E}-04 \\
(0.439) \\
\end{array}$ & $\begin{array}{c}-0.016 \\
(-1.129) \\
\end{array}$ & $54 \%$ \\
\hline 19 & Shanxi Lanhua Sci-Tech Venture & $\begin{array}{l}1.173^{*} \\
(11.765)\end{array}$ & $\begin{array}{c}-0.009 \\
(-0.367)\end{array}$ & $\begin{array}{l}-5.4 \mathrm{E}-04 \\
(-0.392) \\
\end{array}$ & $\begin{array}{l}-6.2 \mathrm{E}-05 \\
(-0.205) \\
\end{array}$ & $\begin{array}{c}-0.017 \\
(-1.206)\end{array}$ & $56 \%$ \\
\hline 20 & China Railway Tielong Container & $\begin{array}{c}0.905^{*} \\
(9.658)\end{array}$ & $\begin{array}{l}7.5 \mathrm{E}-04 \\
(0.040)\end{array}$ & $\begin{array}{c}-9.2 \mathrm{E}-04 \\
(-0.742)\end{array}$ & $\begin{array}{l}-2.0 \mathrm{E}-05 \\
(-0.081)\end{array}$ & $\begin{array}{c}-0.016 \\
(-1.137)\end{array}$ & $53 \%$ \\
\hline
\end{tabular}

Notes:

1. Asymptotic t-statistics appear in parenthesis.

2. Newey and West (1987) procedures for the estimate of regression coefficients on the robust standard errors for consistent heteroskedasticity and autocorrelation have been used.

3. ${ }^{\star}$ Statistically significant at $5 \%$ significance level.

4. ${ }^{* *}$ Statistically significant at $10 \%$ significance level.

5. ${ }^{* *}$ Statistically significant at $15 \%$ significance level. 
numbers (i.e., central limit theorem). The distributions of temperature and rain data are highly nonnormal and shown to have unit roots as null hypothesis of ADF is accepted at 5\% significance level.

As Table 2 outlines, beta coefficients of 19 firms are highly statistically significant at $5 \%$ significance level. Coefficient $\beta_{1}$ that measures the magnitude of changes in stock return in response to corporate cultural behavior becomes negative and statistically significant for 4 firms (2 firms at $5 \%$ significance level and 2 firm at $10 \%$ significance level) rejecting the null hypothesis of the study. More importantly, the coefficient $\beta_{1}$ is negative for 15 firms in the sample which establishes the expected relationship between corporate cultural behavior and common stock return. The significance depends on the extent to which the firms align their corporate actions (or cultural behaviour) with the expectations of shareholders. As Table 4 shows, the total and the average Standardized Dividend Yield (SDY) (reflects the basic idea of Treynor (1965)) of 3 firms whose coefficient $\beta_{1}$ becomes significantly negative are substantially higher than the total and the average SDY of 15 firms whose $\beta_{1}$ is not statistically significant and negative. These results imply that the corporate cultural behavior impacts stock returns only when the corporate actions are directed towards shareholder wealth maximization. When corporate actions do not lead to compensate its shareholders (or the corporate culture is not aligned with shareholder wealth maximization principle), the attention of equity investors (traders) is not drawn to firm-specific operational events/segments and, as such, the corporate cultural behaviour does not impact stock returns of such firms. The coefficient of temperature $\left(\beta_{2}\right)$ is negative and statistically significant for only one firm and none of the coefficients of rain $\left(\beta_{3}\right)$ is negative and statistically significant in the model specification (03).

Alignment of corporate culture (corporate actions) with shareholder wealth maximization principle could be measured, for instance, by the extent to which the firm compensates its equity holders in the form of dividends. The number of times or the average divided distribution during the sampling period does not indicate the true equity compensation because the equity investors are exposed to market risk at different degrees of operations of each firm which is beyond their direct control. Firms' managers need to pay attention to this aspect in order to manage shareholder risk as a practice of good governance. The firms' operations critically impact the extent to which the equity holders could reduce their exposures to systemic risk by appropriately diversifying the stock portfolios. As such, the equity compensation should be estimated with reference to systematic risk of the security (or firm) in question.

Shareholders are more concerned about their stake and whether the firm aligns the corporate culture (corporate actions) with shareholder wealth maximization principle, for example, adequately diversifying the business portfolio in order to eliminate the excessive risk and provides a decent return to stock holders, commensurate with the market risk. As such, these firms do not provide sufficient amount of payoffs for equity holders by taking appropriate corporate actions in managing the funds invested in the firms' equity capital.

The coefficient $\beta_{6}$ under logit regression is negative for 19 firms in the sample. 
Table 3. Details of equity compensation

\begin{tabular}{|c|c|c|c|c|c|c|c|c|}
\hline No & Firm & $\begin{array}{c}\text { Total } \\
\text { Dividend }\end{array}$ & $\begin{array}{l}\text { Avg. } \\
\text { Dividend }\end{array}$ & $\begin{array}{l}\text { Avg. } \\
\text { Dividend } \\
\text { Yield } \\
\text { (DY) }\end{array}$ & Times & $\begin{array}{l}\text { Avg. } \\
\text { Price }\end{array}$ & $\begin{array}{l}\text { Systematic } \\
\text { Risk (SR) }\end{array}$ & DY/SR \\
\hline 1 & $\begin{array}{l}\text { Kunwu Jiuding Invest- } \\
\text { ment Holdings }\end{array}$ & 1.035 & 0.148 & 0.022 & 7.000 & 6.780 & 0.000 & $8932 \%$ \\
\hline 2 & Citic Guoan Wine & 0.025 & 0.025 & 0.004 & 1.000 & 5.640 & 0.808 & $0.55 \%$ \\
\hline 3 & China Meheco & 3.371 & 0.211 & 0.042 & 16.000 & 5.050 & 1.391 & $3.00 \%$ \\
\hline 4 & $\begin{array}{c}\text { China Resources } \\
\text { Double-Crane }\end{array}$ & 2.753 & 0.184 & 0.017 & 15.000 & 10.860 & 0.189 & $8.96 \%$ \\
\hline 5 & $\begin{array}{c}\text { Shanghai Maling } \\
\text { Aquarius }\end{array}$ & 0.685 & 0.114 & 0.031 & 6.000 & 3.640 & 0.698 & $4.49 \%$ \\
\hline 6 & Xinjiang Tianye Co. & 0.505 & 0.063 & 0.012 & 8.000 & 5.210 & 0.893 & $1.36 \%$ \\
\hline 7 & $\begin{array}{c}\text { China Cyts Tours } \\
\text { Holding }\end{array}$ & 2.550 & 0.142 & 0.019 & 18.000 & 7.480 & 0.720 & $2.63 \%$ \\
\hline 8 & Hubei Xingfa Chemicals & 2.345 & 0.130 & 0.013 & 18.000 & 9.770 & 0.976 & $1.37 \%$ \\
\hline 9 & Sundy Land Investment & 0.218 & 0.036 & 0.009 & 6.000 & 3.890 & 1.475 & $0.63 \%$ \\
\hline 10 & $\begin{array}{l}\text { Eastern Gold Jade } \\
\text { Company }\end{array}$ & 0.389 & 0.078 & 0.019 & 5.000 & 4.030 & 0.871 & $2.22 \%$ \\
\hline 11 & $\begin{array}{c}\text { Easysight Supply Chain } \\
\text { Management }\end{array}$ & 0.407 & 0.102 & 0.017 & 4.000 & 5.900 & 0.448 & $3.85 \%$ \\
\hline 12 & $\begin{array}{c}\text { Guangzhou Development } \\
\text { Group }\end{array}$ & 3.288 & 0.183 & 0.035 & 18.000 & 5.240 & 1.074 & $3.25 \%$ \\
\hline 13 & $\begin{array}{l}\text { Sichuan Mingxing Elec- } \\
\text { tric Power Co }\end{array}$ & 1.158 & 0.083 & 0.010 & 14.000 & 8.450 & 0.849 & $1.15 \%$ \\
\hline 14 & Jiangsu Etern Co., Ltd. & 1.457 & 0.104 & 0.038 & 14.000 & 2.740 & 1.480 & $2.57 \%$ \\
\hline 15 & $\begin{array}{c}\text { Zhe Jiang Dong Ri Co., } \\
\text { Ltd }\end{array}$ & 0.917 & 0.083 & 0.018 & 11.000 & 4.720 & 0.832 & $2.12 \%$ \\
\hline 16 & $\begin{array}{c}\text { Jinyu Bio-Technology } \\
\text { Co., Ltd }\end{array}$ & 3.182 & 0.212 & 0.051 & 15.000 & 4.150 & 0.832 & $6.15 \%$ \\
\hline 17 & $\begin{array}{c}\text { Chongqing Three Gorges } \\
\text { Water }\end{array}$ & 1.240 & 0.095 & 0.040 & 13.000 & 2.360 & 0.636 & $6.36 \%$ \\
\hline 18 & $\begin{array}{c}\text { Jiangsu Hongtu High } \\
\text { Technology }\end{array}$ & 0.476 & 0.053 & 0.009 & 9.000 & 5.660 & 0.804 & $1.16 \%$ \\
\hline 19 & $\begin{array}{c}\text { Shanxi Lanhua Sci-Tech } \\
\text { Venture }\end{array}$ & 4.185 & 0.279 & 0.036 & 15.000 & 7.780 & 1.893 & $1.89 \%$ \\
\hline 20 & $\begin{array}{c}\text { China Railway Tielong } \\
\text { Container }\end{array}$ & 0.914 & 0.070 & 0.015 & 13.000 & 4.830 & 0.671 & $2.17 \%$ \\
\hline
\end{tabular}

Note: Systematic Risk (SR) is computed as $\sigma_{m t}^{2} \beta_{m}^{2}$. 
This confirms that the temperature negatively impacts the likelihood of occurrence of positive returns. Coefficient $\beta_{6}$ of 10 firms is statistically significant at varying significance levels (4 firms at 5\% significance level, 4 firms at $10 \%$ significance level and 2 firms at $15 \%$ significance level). The corresponding estimated probabilities of observing positive return under the specification (4) or (6) are reported in Table 2. The recorded probability is $55 \%$ on average (20 firms).

As compensation details provided in Table 4 , stocks of firms whose $\beta_{1}$ becomes negative and statistically significant do not demand a greater premium for systematic risk (0.63) when compared with the stockholders of other firms whose $\beta_{1}$ is not statistically significant (0.95). Note that the risk premium claimed on financial leverage is assumed to be zero. Meeting shareholder expectations in terms of firms-specific (corporate) actions (for example, investment in a positive net present value investment project in order to increase Return on Equity (ROE)) is expected to be weaker in these firms as shareholder returns are determined largely by the information segments or events that are beyond the direct control of individual firms (e.g. economic and political factors). As such, trading on these information variables, without sufficient payoffs accruing from individual firm-specific events or corporate actions, requires shareholders to demand an additional risk premium (see the comparison made in Table 4).

\section{Conclusion}

E. M. Saunders (1993) and many others have shown that the human behaviour determines the magnitude of price changes. Primarily, this proposition has been defended in the literature considering mood state of individual investors altered by weather variables, although it is soundly rejected in some instances (see especially Krämer and Runde, 1997). When 'people' are attached to a particular work setting, a specific behaviour is formed which distinguishes from the behaviour of 'people' when they are not constrained by a corporate specific value system. As such, it is highly likely that the corporate specific behaviour may impact the return of equity holders.

\section{Table 4. Summary of equity compensation and regression results}

\begin{tabular}{|c|c|c|c|c|}
\hline \multirow{2}{*}{ Element } & \multicolumn{2}{|c|}{$\beta_{1}$ is statistically significant and negative } & \multicolumn{2}{c|}{$\beta_{1}$ is not statistically significant } \\
& $\left(3\right.$ firms $\left.{ }^{*}\right)$ & Total & Average \\
\cline { 2 - 5 } & Total & Average & 19.05 & 1.27 \\
\hline Total Dividend & 7.65 & 2.55 & $34.54 \%$ & $2.30 \%$ \\
\hline Dividend Yield (DY) & $4.92 \%$ & $1.64 \%$ & 152.00 & 10.13 \\
\hline No. of times** & 51.00 & 17.00 & 14.26 & 0.95 \\
\hline Systematic Risk (SR) & 1.88 & 0.63 & $39.92 \%$ & $2.66 \%$ \\
\hline SDY=DY/SR & $12.96 \%$ & $4.32 \%$ & & \\
\hline
\end{tabular}

Notes:

1. ${ }^{*}$ Firm 1 has been eliminated from the comparison due to substantially lower coefficient $\beta_{m}$ reported.

2. ${ }^{* *}$ Paid during the sample period. 
The regression of common stock returns on the numerical variable computed for corporate cultural behaviour produces statistically significant negative coefficients for only three firms whose corporate actions, derived from corporate specific behaviour, are directed towards shareholder wealth maximization. As such, the corporate cultural behaviour does not impact stock returns when firms do not align their operations with the interest of shareholders. The results also reveal that, when the firms pay less attention (by way of equity compensation) to its shareholders in the course of operation, the corporate culture does not impact the return required by the ordinary shareholders as their trading is not justified by operational information segments or events under direct control of the organizations. Rather, the equities are traded largely on the information segments or events that are beyond the direct control of individual firms (e.g., economic and political factors).

The appropriateness of temperature as a proxy variable for mood state of individual investors has been testified by the sign of logit regression coefficients. The results also reveal that the mood proxied by temperature has a negative impact on the like- lihood of observing positive returns and the estimated probabilities are above average. Premium for market risk as measured by the systematic risk of individual firms is substantially high, when the firms do not compensate (as measured by SDY) equity holders commensurate with the market risk. These findings suggest that the organizational culture plays a key role in shareholder risk management under corporate governance. Therefore, the managers should listen to the market and understand the behaviour of price change process of common stocks as a part of their exercise of corporate governance.

\section{Acknowledgments}

The author would like to thank the Editorin-chief Giedrius Jucevičius and the Managing Editor, Zigmas Lydeka. An unknown reviewer provided helpful comments on the earlier version of this paper. A note of thanks is due to Edita Eičiuvienè for pleasant editorial assistance. The author would also like to thank Karen Regon for her generosity in sharing the Microsoft macros for sorting and matching large amount of time series data. Usual disclaimer applies.

\section{References}

1. Abdul Rashid, Z., Sambasivan, M., Johari, J. (2003). The Influence of Corporate Culture and Organisational Commitment on Performance // Journal of Management Development. Vol. 22, No. 8, pp. 708-728. doi: http://dx.doi. org/10.1108/02621710310487873.

2. Agwu, M. O. (2014). Organizational Culture and Employees Performance in the National Agency for Food and Drugs Administration and Control (Nafdac), Nigeria // Global Journal of Management and Business Research. Vol. 14, No. 2. Internet access: https://globaljournals. org/GJMBR_Volume14/1-OrganizationalCulture-and-EmployeesPerformance.pdf.

3. Ajzen, I. (1991). The Theory of Planned Behavior // Organizational Behavior and Human Decision Processes. Vol. 50, No. 2, pp. 179-211. doi: http:// dx.doi.org/10.1016/0749-5978(91)90020-T.

4. Asker, J., Farre-Mensa, J., Ljungqvist, A. (2014). Corporate Investment and Stock Market Listing: 
A Puzzle? // The Review of Financial Studies. Vol. 28, No. 2, pp. 342-390. doi: http://dx.doi. org/10.1093/rfs/hhu077.

5. Black, F. (1972). Capital Market Equilibrium with Restricted Borrowing // The Journal of Business. Vol. 45, No. 3, pp. 444-455. doi: http:// dx.doi.org/10.1086/295472.

6. Cao, M., Wei, J., (2005). Stock Market Returns: A Note on Temperature Anomaly // Journal of Banking and Finance. Vol. 29, No. 6, pp. 1559-1573. doi: http://dx.doi.org/10.1016/j. jbankfin.2004.06.028.

7. Clark, P. K. (1973). A Subordinated Stochastic Process Model with Finite Variance For Speculative Prices // Econometrica. Vol. 41, No. 1, pp. 135-155. doi: http://dx.doi. org/10.2307/1913889.

8. Comment, R., Schwert, G. W. (1995). Poison or Placebo? Evidence on the Deterrence and Wealth Effects of Modern Antitakeover Measures // Journal of Financial Economics. Vol. 39, No. 1, pp. 3-43. doi: http://dx.doi. org/10.1016/0304-405X(94)00823-J.

9. Cuñat, V., Gine, M., Guadalupe, M. (2012). The Vote Is Cast: The Effect of Corporate Governance on Shareholder Value // The Journal of Finance. Vol. 67, No. 5, pp. $1943-1977$.

10. De Jong, E., Semenov, R. (2002). Cross-Country Differences in Stock Market Development: A Cultural View. Paper Presented at the EFA 2002 Berlin Meetings University of Groningen, Research School, 4 Mar. doi: http://dx.doi. org/10.2139/ssrn.301374.

11. Denison, D. R. (1990). Corporate Culture and Organizational Effectiveness. - New York, NY: John Wiley \& Sons.

12. Fama, E. F. (1965). The Behavior of StockMarket Prices // The Journal of Business. Vol. 38, No. 1, pp. 34-105. doi: http://dx.doi. org/10.1086/294743.

13. George, J.M., Jones, G.R. (1996). The Experience of Work and Turnover Intentions: Interactive Effects of Value Attainment, Job Satisfaction, and Positive Mood // Journal of Applied Psychology. Vol. 81, No. 3, pp. 318-325. doi: http://dx.doi.org/10.1037/0021-9010.81.3.318.

14. Gordon, G. G., DiTomaso, N. (1992). Predicting Corporate Performance From Organizational Culture // Journal of Management Studies. Vol. 29, No. 6, pp. 783-798. doi: http://dx.doi. org/10.1111/j.1467-6486.1992.tb00689.x.

15. Hirshleifer, D., Shumway, T. (2003). Good Day Sunshine: Stock Returns and the
Weather // The Journal of Finance. Vol. 58, No. 3, pp. 1009-1032. doi: http://dx.doi. org/10.1111/1540-6261.00556.

16. Hofstede, G. (1985). The Interaction Between National and Organizational Value Systems // Journal of Management Studies. Vol. 22, No. 4, pp. 347-357. doi: http://dx.doi. org/10.1111/j.1467-6486.1985.tb00001.x.

17. Hofstede, G. (1994). The Business of International Business Is Culture // International Business Review. Vol. 3, No. 1, pp. 1-14. doi: http:// dx.doi.org/10.1016/0969-5931(94)90011-6.

18. Hofstede, G. (2001). Culture's Recent Consequences: Using Dimension Scores in Theory and Research // International Journal of Cross Cultural Management. Vol. 1, No. 1, pp. 11-17. doi: http://dx.doi. org/10.1177/147059580111002.

19. Kadyrzhanova, D., Rhodes-Kropf, M. (2011). Concentrating on Governance // The Journal of Finance. Vol.66, No.5,pp. 1649-1685.doi: http:// dx.doi.org/10.1111/j.1540-6261.2011.01684.x.

20. Kant, K. (2017). Right Culture Can Double Corporate Profitability. [online] Businessstandard.com. Internet access: http://www. business-standard.com/article/companies/ right-culture-can-double-corporateprofitability-115071600620_1.html.

21. Keef, S. P., Roush, M. L. (2007). Daily Weather Effects on the Returns of Australian Stock Indices // Applied Financial Economics. Vol. 17, No. 3, pp. 173-184. doi: http://dx.doi. org/10.1080/09603100600592745.

22. Keller, M.C., Fredrickson, B.L., Ybarra, O., Côté, S., Johnson, K., Mikels, J., Conway, A., Wager, T. (2005). A Warm Heart and A Clear Head: the Contingent Effects of Weather on Mood and Cognition // Psychological Science. Vol. 16, No. 9, pp. 724-731. doi: http://dx.doi. org/10.1111/j.1467-9280.2005.01602.x.

23. Kotter, J. (2012). Corporate Culture and Performance. - New York, NY: Free Press

24. Kotter, J. P., Heskett, J. L. (1992). Corporate Culture and Performance. - New York: The Free Press.

25. Krämer, W., Runde, R. (1997). Stocks and the Weather: An Exercise in Data Mining or Yet Another Capital Market Anomaly? // Empirical Economics. Vol. 22, No. 4, pp. 637 -641. doi: http://dx.doi.org/10.1007/BF01205784.

26. Lamoureux, C. G., Lastrapes, W. D. (1990). Heteroskedasticity in Stock Return Data: Volume Versus GARCH Effects // The Journal 
of Finance. Vol. 45, No. 1, pp. 221-229. doi: http://dx.doi.org/10.1111/j.1540-6261.1990. tb05088.x.

27. Li, K., Griffin, D., Yue, H., Zhao, L. (2013). How Does Culture Influence Corporate Risk-Taking? // Journal of Corporate Finance. Vol. 23, pp. 1-22. doi: http://dx.doi.org/10.1016/j. jcorpfin.2013.07.008.

28. Lok, P., Crawford, J. (2004). The Effect of Organisational Culture and Leadership Style on Job Satisfaction and Organisational Commitment: a Cross-National Comparison // Journal of Management Development. Vol. 23, No. 4, pp. 321-338. doi: http://dx.doi. org/10.1108/02621710410529785.

29. Lunenburg, F. C. (2012). Organizational Structure: Mintzberg's Framework // International Journal of Scholarly, Academic, Intellectual Diversity. Vol. 14, No. 1, pp. 1-8.

30. Mihet, R. (2013). Effects of Culture on Firm Risk-Taking: a Cross-Country and CrossIndustry Analysis // Journal of Cultural Economics. Vol. 37, No. 1, pp. 109-151. doi: http://dx.doi.org/10.1007/s10824-012-9186-2.

31. Popadak, J., (2015). A Corporate Culture Channel: How Increased Shareholder Governance Reduces Firm Value - Working Paper. University of Pennsylvania. doi: http:// dx.doi.org/10.2139/ssrn.2345384.

32. Ravasi, D., Schultz, M. (2006). Responding to Organizational Identity Threats: Exploring the Role of Organizational Culture // Academy of Management Journal, Vol. 49(3), pp. 433-458. doi: 10.5465/AMJ.2006.21794663.

33. Rest, J. (1986). Moral Development: Advances in Research and Theory. - New York, NY: Praeger.

34. Roll, R., (1988). The Stochastic Dependence of Security Price Changes and Transaction Volumes: Implications for the Mixture-ofDistributions Hypothesis. // Journal of Finance. Vol. 43, No. 3, pp. 541-566. doi: http://dx.doi. org/10.1111/j.1540-6261.1988.tb04591.x.

35. Saunders, E. M. (1993). Stock Prices and Wall Street Weather // The American Economic Review. Vol. 83, No. 5, pp. $1337-1345$.

36. Schneider, S. C. (1988). National vs. Corporate Culture: Implications for Human Resource Management // Human Resource Management. Vol. 27, No. 2, pp. 231-246. doi: http://dx.doi. org/10.1002/hrm.3930270207.

37. Schrodt, P (2002). The Relationship Between Organizational Identification and
Organizational Culture: Employee Perceptions of Culture and Identification in A Retail Sales Organization // Communication Studies. Vol. 53, No. 2, pp. 189-202. doi: http://dx.doi. org/10.1080/10510970209388584.

38. Schuler, R. S., Rogovsky, N. (1998). Understanding Compensation Practice Variations Across Firms: the Impact of National Culture // Journal of International Business Studies. Vol. 29, No. 1, pp. 159 -177. doi: http:// dx.doi.org/10.1057/palgrave.jibs.8490030.

39. Senarathne, C. W., Jayasinghe, P. (2017). Information Flow Interpretation of Heteroskedasticity for Capital Asset Pricing: An Expectation-based View of Risk // Economic Issues. Vol. 22, No. 1, pp. 1-24.

40. Senarathne, C. W., Jianguo, W. (2017). The Impact of Patent Citation Information Flow of Economic Innovation on Common Stock Returns: Volume Vs Patent Citations. - Working Paper, Wuhan University of Technology, School of Economics.

41. Senarathne, C. W., Long, W. (2018). Industry Competition and Common Stock Returns. Working Paper, Wuhan University of Technology, School of Economics.

42. Senarathne, C.W., Jianguo, W., Wijesundara, T. (2017). The Relationship between Human Behavior and Stock Returns in Efficient Stock Markets: The Mood-effect under Cultural Perspective. - Working paper, Wuhan University of Technology, School of Economics.

43. Shrafritz, J., Ott, J. S. (1992). Organizational Culture and Leadership: A Dynamic View. - San Francisco: Jossey-Bass.

44. Smith, A. (2002). Effects of Caffeine on Human Behavior // Food and Chemical Toxicology. Vol. 40, No. 9, pp. 1243 -1255. doi: http://dx.doi. org/10.1016/S0278-6915(02)00096-0.

45. Smith, P. B., Dugan, S., Trompenaars, F. (1996). NationalCultureand the ValuesofOrganizational Employees: A Dimensional Analysis Across 43 Nations // Journal of Cross-cultural Psychology, Vol. 27, No. 2, pp. 231--264. doi: http://dx.doi. org/10.1177/0022022196272006.

46. Tobin, J. (1984). On the Efficiency of the Financial System // Lloyd's Banking Review. Vol. 153, pp. $1-15$.

47. Treynor, J. L. (1965). How to Rate Management of Investment Funds // Harvard Business Review. Vol. 43, No. 1, pp. $63-75$.

48. Verbeek, M. (2008). A Guide to Modern Econometrics. - Chichester: John Wiley \& Sons. 
49. Yermack, D. (2006). Flights of Fancy: Corporate Jets, CEO Perquisites, and Inferior Shareholder Returns // Journal of Financial Economics. Vol. 80, No. 1, pp. 211-242. doi: http://dx.doi. org/10.1016/j.jfineco.2005.05.002.

50. Zhang, Q., Ni, X., Zhang, F. (2017). Decreasing Trend in Severe Weather Occurrence Over
China During the Past 50 Years // Scientific Reports. Vol. 7, No. 1. doi: http://dx.doi. org/10.1038/srep42310

The paper submitted: November 20, 2018

Prepared for publication: December 27, 2018

Chamil W. SENARATHNE

\section{İMONIỤ KULTŪRINIO ELGESIO İTAKA BENDRAJAI AKCIJŲ GRAZŽAI: KELETAS İMONIỤ VALDYMO PADARINIŲ}

\section{$\mathrm{S}$ a n t r a u k a}

Kiekviena verslo organizacija siekia pelno, o tai galiausiai lemia pagrindinių akcininkų turtą. Verslo veiklos metu organizacinių išteklių paskirstymas tarp verslo funkcijų (pavyzdžiui, rinkodara, operacijos) yra kritiškai svarbūs sprendimai, turintys įtakos i̇monés verslo strategijai. Siekiant maksimaliai panaudoti pagrindinių akcininkų turtą, vadovai turi užtikrinti, kad organizaciniai ištekliai būtų veiksmingai ir efektyviai paskirstyti tarp verslo funkcijų, nes bendroji pelno norma eiliniams akcininkams yra nustatoma pagal bendrą verslo pajamų sumą. Kiekvieną organizacijos funkciją reglamentuoja organizacijos vertybių rinkinys. Siekiant finansinių tikslų ypač svarbu kiekybiškai ịvertinti ir apsvarstyti verslo vertybes (verslo kultūros vertybes). Kita vertus, verslo vertybių sistema turi ịtakos verslo strategijai ir organizacijos veiklai.

Šio straipsnio tikslas - išnagrinèti santykị tarp bendrosios akcijų grąžos ir įmonių kultūrinio elgesio dvidešimtyje atsitiktinai atrinktų Šanchajaus akcijų biržos įmonių. Konkretūs šio tyrimo klausimai: ar įmonių kultūrinis elgesys daro ịtaką bendrajai akcijų grąžai ir kokiomis sąlygomis ši ịtaka daroma akcininkų lūkesčiams ir įmonių valdymui. Tyrimo užduotys ir metodai apima kintamojo C vertę, atspindinčią įmonių kultūrinị elgesị pagal konceptualųji pagrindą ir taikant ịprastą mažiausių kvadratų (angl. Ordinary Least Square, OLS) regresijos metodą, siekiant nustatyti ịmonių kultūrinio elgesio poveikį bendrajai akcijų grąžai. Be to, dvejetainès logistinès regresijos modelis naudojamas siekiant suprasti temperatūros vaidmens pagrịstumą skaičiavimuose ir galutinèse regresijose.

Bendrosios akcijų grąžos mažèjimas skaičiuojant skaitinị kintamąji, kuris susijęs su įmonių kultūriniu elgesiu, rastas statistiškai reikšmingas neigiamas koeficientas tik trijose immonèse, kurių korporaciniai veiksmai, kylantys dèl įmonių specifinio elgesio, yra nukreipti $\mathfrak{i}$ akcininkų turto didinimą. Taigi, įmonių kultūrinis elgesys neturi ịtakos bendrajai akcijų grąžai, kai ̨̨monès nesuderina savo veiklos su akcininkų interesais. Rezultatai taip pat atskleidžia, kad tuomet, kai įmonès savo veikloje skiria mažiau dèmesio savo eiliniams akcininkams (nuosavybès kompensavimo būdu), įmonès kultūra nedaro ịtakos paprastų akcininkų reikalaujamoms pajamoms, nes su jais susijusi prekyba nèra pagrịsta veiklos informacijos segmentais ar ịvykiais, kuriuos tiesiogiai kontroliuoja organizacijos. Šiuo atveju akcijomis prekiaujama daugiausia informacijos segmentuose ar ịvykiuose, kurie nepriklauso nuo tiesioginès atskirų įmonių kontrolès (pavyzdžiui, daug lemia ekonominiai ir politiniai veiksniai).

Temperatūros pokyčių kaip individualių investuotojų nuotaikos būsenos kintamojo tinkamumą liudija logistinès regresijos koeficientų žymuo. Rezultatai taip pat atskleidžia, kad temperatūra išreikšta nuotaika neigiamai veikia teigiamos grąžos tikimybę, o apskaičiuotos tikimybès yra didesnès už vidurkị. Priemoka už rinkos riziką, apskaičiuotą pagal atskirų įmonių sisteminę riziką, iš esmès yra didelè, kai įmonès nemoka kompensacijų (pagal SDY vertinimą) akcininkams, atitinkantiems rinkos riziką. Šie faktai rodo, kad organizacinè kultūra vaidina pagrindinị vaidmenị įmonès valdyme, susijusiame su akcininkų rizikos vadyba. Todèl vadovai turètų ịsiklausyti ị rinką ir stengtis suprasti bendrųjų akcijų kainų pokyčiu procesą kaip labai svarbų įmonès valdymui. 